NOTE

\title{
Flow cytometric characterization and enumeration of Chrysochromulina polylepis during a bloom along the Norwegian coast
}

\author{
Knut Yngve Børsheim ${ }^{1}$, Torstein Harboe ${ }^{2}$, Torbjørn Johnsen $^{3}$, Svein Norland ${ }^{1}$, Kari Nygaard ${ }^{2}$ \\ ' Dept of Microbiology and Plant Physiology, University of Bergen, Allégt. 70, N-5007 Bergen, Norway \\ ${ }^{2}$ Austevoll Marine Aquaculture Station, Institute of Marine Research, N-5392 Storebe, Norway \\ ${ }^{3}$ Dept of Marine Biology, University of Bergen, N-5065 Blomsterdalen, Norway
}

\begin{abstract}
Flow cytometry was used to count the concentration of the alga Chrysochromulina polylepis Manton \& Parke during a bloom along the Western and Southern Norwegian coasts. Fresh samples could be counted without fixation immediately after sampling. Flow-cytometric enumeration of the alga agreed well with direct counting in the microscope. C. polylepis was identified by its characteristic combination of red fluorescence and scatter signal. These signature coordinates did not change significantly with time, depth or concentration. The flow-cytometric measurements could be performed even when the ship was running and in normal rough seas in offshore locations, whereas direct counting was impossible under such circumstances.
\end{abstract}

Flow cytometry has been suggested as a valuable tool for the study of marine microorganisms (Olson et al. 1983, Yentsch et al. 1983a, b, Cucci et al. 1985, Wood et al. 1985). The potential of this technique has been explored and demonstrated in the biochemical literature (Muirhead et al. 1985), but progress in the use of shipboard flow cytomers has been slow. This may be partly because most flow cytometers are sensitive to motor vibration on board a ship, and also to wave motion. The design of most flow cytometers requires focusing a free falling stream of liquid, making shipboard experiments a 'frustrating experience' (Burkill 1987). In addition, in oceanographic investigations, enumeration of particles is desired. Because most flow cytometers have not been designed for counting, the use of internal standards, such as latex beads, are usually necessary for enumeration of particles.

In the study reported here an Argus 100-2 flow cytometer (Skatron, Norway) was used to discriminate and count phytoplankton during a bloom off the Southern and Western Norwegian coasts. This instrument weighs only $45 \mathrm{~kg}$, which makes transportation and installation on board convenient, and incorporates a sample stream which is hydrodynamically focused on the surface of a microscope coverslip (Steen \& Lindmo 1979, Steen 1983). This design is different from other flow cytometers, and proved to function even when the ship was steaming at 11 knots and in offshore waters. The instrument also incorporates a volumetrically quantitative injection system that allows direct counting of particle concentrations without the addition of internal standards.

Materials and methods. The expedition was part of a surveillance effort to map the distribution and movement of a fish killing bloom of Chrysochromulina polylepis Manton \& Parke. The bloom started in the Kattegat in early May 1988, and was carried north with the Baltic Current. The bloom was first detected on the coast of Norway on 12 May (Einar Dahl, Marine Research Station Flødevigen, Arendal, Norway, pers. comm), where it caused severe damage to coastal marine invertebrates and fish (Saunders 1988).

The measurements reported here were carried out on samples collected by 21 Niskin bottles from RV 'Haakon Mosby' between $58^{\circ} 11^{\prime} \mathrm{N}$ and $60^{\circ} \mathrm{N}$, on 25 and 28 May 1988.

Identification and counting of phytoplankton was done using a standard Leitz Labolux microscope and a Fuchs Rosenthal counting chamber. Positive taxonomic identification of the species Chrysochromulina polylepis (Manton \& Parke 1962) was based on electron microscope studies (Jahn Throndsen, University of Oslo, Norway, pers. comm.)

Untreated water samples were analyzed within 20 min of sampling using an Argus 100-2 flow cytometer (Skatron A/S, Norway) at a flow rate of $6 \mu \mathrm{l} \mathrm{min}{ }^{-1}$. 

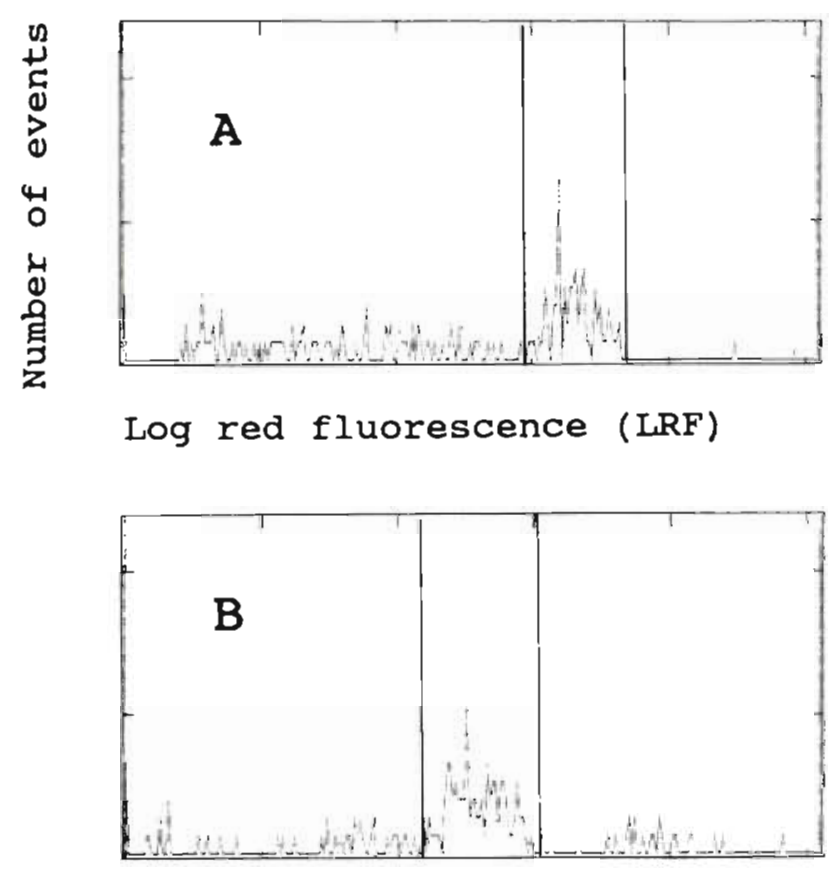

Log light scatter (LLS)

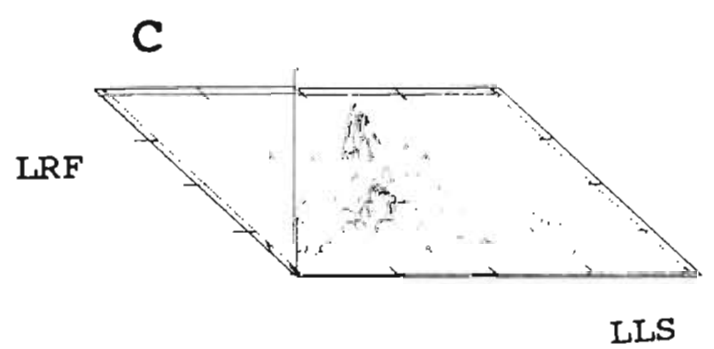

Fig. 1. Chrysochromulina polylepis. Flow cytometric spectra from the beginning of the bloom. Framed areas in (A) and (B) indicate the signature coordinates of this species. (C) 3-dimensional presentation of combined data from (A) und (B)

Measurements were based on scatter signal and red fluorescence. Both detector signals were processed with a logarithmic amplifier, to expand the measuring range. Data acquisition was triggered by the fluorescence signal. The light source was a $100 \mathrm{~W}$ high pressure Mercury UV lamp. To correct for drift in signal, e.g. due to fading of lamp intensity, fluorescent monodisperse latex beads were analyzed every $24 \mathrm{~h}$.

Estimation of concentrations from counts was based on data acquisition time and sample flow rate. The standard acquisition time used was $5 \mathrm{~min}$. Based on counting statistics, we estimate the detection limit to be ca 50 cells $\mathrm{ml}^{-1}$.

Results and discussion. Fig. 1 presents one set of results from the flow cytometer on a sample from the algal bloom. The vertical lines show the peak that we assumed to correspond to Chrysochromulina polylepis.

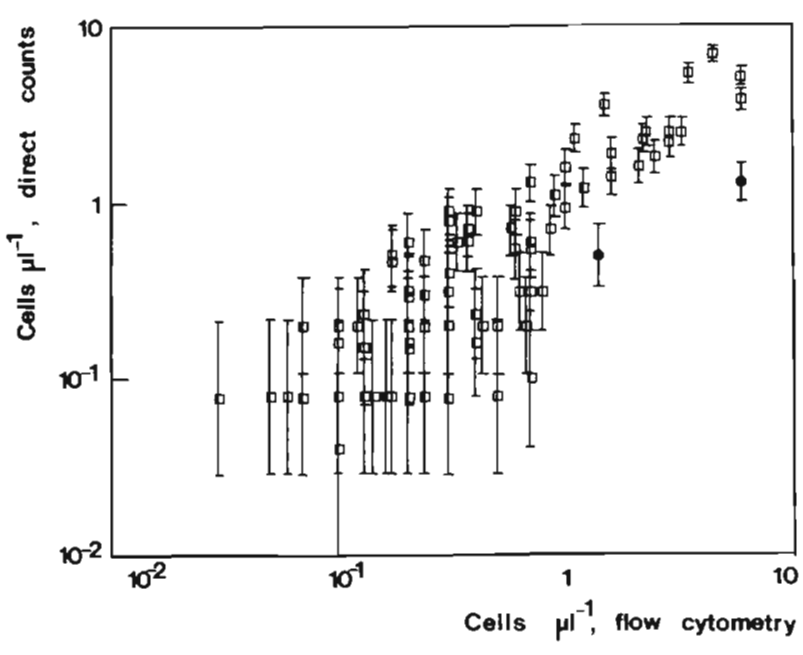

Fig. 2. Chrysochromulina polylepis. Alga counted with flow cytometry and in a microscope counting chamber. Vertical bars indicate standard errors as calculated from counting statistics. Filled circles are from the late phase of the bloom (see text)

Microscopic observations revealed that at this early stage of the bloom, C. polylepis constituted an almost monoculture. Such samples were used to set the range of scatter and fluorescence coordinates for normal cells of C. polylepis. Later, these coordinates were used for counting C. polylepis when it was subdominant. Fig. 2 shows results from 64 samples taken from 2 and $10 \mathrm{~m}$ depth at various stations during the cruise. In most samples $C$. polylepis was found both with microscope and flow cytometry. In the majority of the samples, the microscope counts agreed with the counts from the flow cytometer, but in 2 samples from the later phase of the bloom the 2 methods disagreed (filled circles in Fig. 2). Microscopic analysis indicated that C. polylepis cells from these samples disintegrated easily, presumably because of poor physiological condition. This did not create a problem for counting these cells in the flow cytometer.

Other abundant phytoplankters such as the coccolithophorid Emilian huxleyi which dominated north of the Chrysochromulina polylepis bloom, and Synechococcus spp., which were common in samples from 15 and $20 \mathrm{~m}$ depth, could also be enumerated once their signature coordinates had been established.

Our general experience from this expedition is that once the signature coordinates have been established, flow cytometry is a convenient way to count individual species of phytoplankton at sea. During blooms of algae that may cause threats to economic interests such as fisheries or fish breeding plants, fast and reliable mapping of the bloom may be obtained with reasonable labour effort using flow cytometry of fresh samples. We used only autofluorescence and one scatter signal in this investigation. The instrument can be equipped with detectors for both high angle and low angle scatter 
(Muirhead et al. 1985), and detectors for fluorescence in more than one wavelength band. By increasing the number of detected parameters for each cell, the reliability of the detection of phytoplankton species can be increased (Yentsch \& Yentsch 1979, Yentsch \& Phinney 1985). One of the main problems that still remains is the relatively slow flow rate of the sample in high resolution flow cytometers. This makes the investigation of organisms in low concentrations time-consuming or even impossible. The advantage of being able to investigate undisturbed unfixed material is lost when concentrating or fixation procedures have to be applied. Therefore, it seems that at present shipboard flow cytometry is most suited for studying dominant organisms.

Acknowledgements. We thank Gunnar Bratbak and T Frede Thingstad for help with planning and preparing the expedition, and Christopher D. Hewes and Ian Dundas for criticism of an earlier version of the manuscript. We also thank the leader of the expedition, Arne Johansen, and the crew of RV 'Håkon Mosby' for their cooperation.

\section{LITERATURE CITED}

Burkill, P. H. (1987). Analytical flow cytometry and its application to marine microbial ecology. In: Sleigh, M. A. (ed.) Microbes in the sea. Ellis Horwood Ltd., Chichester, p. 139-166

Cucci, T. L., Shumway, S. E., Newell, R. C., Selvin, R., Guillard, R. R. L., Yentsch, C. M. (1985). Flow cytometry: a new method for characterization of differential ingestion, digestion and egestion by suspension feeders. Mar Ecol. Prog. Ser. 24: 201-204

This note was submitted to the editor
Manton, I., Parke, M. (1962). Preliminary observations on scale and their mode of origin in Chrysochromulina polylepis sp. nov. J. mar biol. Ass. U. K. 42: 565-578

Muirhead, K. A., Horan, P. K., Poste, G. (1985). Flow cytometry: present and future. Bio/technol. 3: 337-356

Olson, R. J., Frankel, S. L., Chisholm, S. W., Shapiro, H. M. (1983). An inexpensive flow cytometer for the analysis of fluorescent signals in phytoplankton: chlorophyll and DNA distribution. J, exp. mar. Biol. Ecol. 68: 129-144

Saunders, R. L. (1988). Algal catastrophe in Norway. Wld Aquacult 19 (3): 11-12

Steen, H. B. (1983). A microscope-based flow cytometer. Histochem. J. 15: $147-160$

Steen, H. B., Lindmo, T (1979). Flow cytometry: a highresolution instrument for everyone. Science 204: 403-404

Wood, A. M., Horan, P. K., Muirhead, K., Phinney, D. A., Yentsch, C. M., Waterbury, J. B. (1985). Discrimination between types of pigments in marine Synechococcus spp. by scanning spectroscopy, epifluorescence microscopy, and flow cytometry. Limnol. Oceanogr. 30: 1303-1315

Yentsch, C. M., Horan, P. K., Muirhead, K., Dortch, Q., Haugen, E., Legendre, L., Murphy, L. S., Perry, M. J., Phinney, D. A., Pomponi, S. A., Spinrad, R. W., Wood, M., Yentsch, C. S., Zahuranec, B. J. (1983a). Flow cytometry and cell sorting. A technique for analysis and sorting of aquatic particles. Limnol. Oceanogr 28: 1275-1280

Yentsch, C. M., Mague, F. C., Horan, P. K., Muirhead. K. (1983b). Flow cytometric DNA determinations on individual cells of the dinoflagellate Gonyaulax tamarensis var. excavata. J. exp. mar. Biol. Ecol. 67: 174-183

Yentsch, C. S., Yentsch, C. M. (1979). Fluorescence spectral signatures: the characterization of phytoplankton populations by the use of excitation and emission spectra. J. mar. Res. 37: 471-483

Yentsch, C. S., Phinney, D. A. (1985). Spectral fluorescence: an ataxonomic tool for studying the structure of phytoplankton populations J. Plankton Res. 7: 617-632

Manuscript first received: July 28, 1988 Revised version accepted: April 7, 1989 